\title{
Energy and Exergy Analysis of an Indirect-Mode Natural Convection Solar Dryer for Maize
}

\author{
Isaac N. Simate ${ }^{1}$ \\ ${ }^{1}$ Department of Agricultural Engineering, School of Engineering, University of Zambia, Lusaka, Zambia. \\ Correspondence: Isaac N. Simate, Department of Agricultural Engineering, School of Engineering, University of \\ Zambia, P.O. Box 32379, Lusaka, Zambia.
}

Received: June 6, 2021

Accepted: July 13, 2021

Online Published: July 15, 2021

doi:10.5539/eer.v11n2p19

URL: https://doi.org/10.5539/eer.v11n2p19

\begin{abstract}
The energy and exergy analysis of an indirect-mode natural convection solar dryer for maize grain is presented. Two different sizes of maize grain bed depths of $0.04 \mathrm{~m}$ and $0.02 \mathrm{~m}$ translating into grain loads of $10 \mathrm{~kg}$ and $5 \mathrm{~kg}$ respectively, are used in the study to determine their effects on the collector energy and exergy efficiencies and the drying chamber exergy efficiency. Experiments were carried out using an indirect-mode laboratory solar dryer under a solar simulator with a radiation setting of $634.78 \mathrm{~W} / \mathrm{m}^{2}$. The analysis gave average collector energy efficiencies of $33.3 \%$ and $46.2 \%$ for the $10 \mathrm{~kg}$ and $5 \mathrm{~kg}$ loads, respectively, which are higher than the collector exergy efficiencies of $2.4 \%$ and $2.6 \%$ for the $10 \mathrm{~kg}$ and $5 \mathrm{~kg}$ loads, respectively. The drying chamber exergy efficiencies are $45.2 \%$ and $28.4 \%$ for the $10 \mathrm{~kg}$ and $5 \mathrm{~kg}$ loads, respectively. In view of this, the $5 \mathrm{~kg}$ load is considered to be more efficient at extracting energy from the collector due to higher air flow resulting from its relatively thin grain bed depth of $0.02 \mathrm{~m}$, but less efficient in utilising the extracted energy to evaporate moisture from the grain which has resulted in a lower drying chamber exergy efficiency. Further, the exergy loss in the drying chamber for the $5 \mathrm{~kg}$ load is higher than that in the $10 \mathrm{~kg}$ load as $72.3 \%$ of the exergy entering the drying chamber is lost through emissions as well as destroyed through internal irreversibility compared to $57.0 \%$ for the $10 \mathrm{~kg}$ load.
\end{abstract}

Keywords: energy and exergy, indirect- mode, natural convection, solar dryer, maize

\section{Introduction}

Solar dryers can be classified according to the method of heat transfer to the drying material as indirect through convection of hot air from a solar air heater to the material (Boulemtafes-Boukadoum \& Benzaoui, 2011), direct through solar radiation on to the material (Simate \& Ahrné, 2006), mixed-mode through a combination of direct radiation and hot air to the material (Simate, 1999), or through a combination of direct radiation and conduction of heat from a solid tray where the drying material is placed (Daud \& Simate, 2017). Solar dryers can further be classified in terms of air flow as natural (free) convection (Berinyuy, Tangka \& Weka Fotso, 2012; Adelaja \& Babatope, 2013; Panwar, Kaushik \& Kothari, 2016; Simate \& Cherotich, 2017) or forced convection (Bennamoun, 2012). Despite the difficulties in quantitative understanding of the drying processes, such as non-linear physical processes and material transport properties that are highly dependent on moisture content and temperature, exergy analysis is effective in providing optimal solutions to drying problems (Dincer \& Rosen, 2007). Kumar, Ranjan, Prakash and Shukla (2017) reported that several studies have been done on exergy of the different types of solar dryers with the aim of reducing losses so that the resources can be utilized to the maximum, thereby realizing economic benefits. They concluded that exergy analysis gave better performance evaluation of solar dryer system and that important information regarding processes, losses and causes of destruction could be obtained.

The work potential of a given source of energy which is referred to as the quality of that energy, is dealt with by the second law, while the quantity of energy is dealt with by the first law of thermodynamics (Hepbasli, 2008). Dincer and Rosen (2007) define the exergy of a system as the maximum shaft work that can be done by the system and a reference environment. Akpinar (2018) has noted that the exergy efficiency of solar drying systems is used frequently as an indicator for their sustainability as it shows the level of use of the exergetic inputs within the process. Boulemtafes-Boukadoum and Benzaoui (2011) carried out energy and exergy analysis of the mint drying process in an indirect solar dryer operating in natural convection mode and in a discontinuous way. The 
exergy analysis enabled them to estimate the actual energy supplied for drying as well as the losses of exergy. Hatami, Payganeh and Mehrpanahi (2020), using a dynamic model for an indirect mode solar dryer, carried out thermal analysis using energy and exergy. They found that there was higher exergy at higher air speed resulting in lower irreversibility. Elavarasan, Dhanushkodi and Sudhakar (2018) carried out energy and exergy analyses of natural convection solar drying of cashew nut and observed a linear relationship between the exergy inflow to the drying cabinet and the inlet temperature coming from the collector. Bolaji (2011) carried out exergy analysis to find out the useful energy and its quality that could be obtained from the direct, indirect and mixed mode natural convection solar dryers. The results showed that the indirect and mixed mode solar dryers were more effective in utilizing the captured energy than the direct mode solar dryer.

In a natural convection solar dryer, as is in the current study, the buoyancy driven vertical air flow through the drying chamber is determined by the depth of the drying bed, among other factors, implying that a thin bed will have a higher air flow than a bigger bed for the same size of collector. The effect of bed depth on the energy and exergy of the dryer needs to be studied as it can reveal exergy loss to the surroundings and that destroyed within the boundaries of the solar dryer due to irreversibility and therefore indicate areas of improvement. Therefore the aim of this paper is to determine the effect of two different grain bed depths on energy and exergy of an indirect-mode natural convection solar dryer with vertical air flow through the grain bed. The study involves two maize grain bed depths of $0.04 \mathrm{~m}$ and $0.02 \mathrm{~m}$ which translate into loads of $10 \mathrm{~kg}$ and $5 \mathrm{~kg}$, respectively.

\section{Energy and Exergy Analysis}

\subsection{Solar Dryer}

The energy and exergy analysis is performed on the solar dryer shown in Figure 1. The solar dryer is an indirect type operating under natural convection with air flow over the absorber but under the clear glass. The body of the dryer is made of $20 \mathrm{~mm}$ thick plywood. The dimensions are: Collector: $1.2 \mathrm{~m}$ length by $1.0 \mathrm{~m}$ width by 0.05 $\mathrm{m}$ depth; Drying chamber: $1.0 \mathrm{~m}$ width by $0.19 \mathrm{~m}$ height by $0.34 \mathrm{~m}$ breadth. The drying chamber has a rectangular exit vent measuring $1.0 \mathrm{~m}$ length by $0.05 \mathrm{~m}$ width. Grain bed depth in the drying chamber is $0.04 \mathrm{~m}$ for the $10 \mathrm{~kg}$ load and $0.02 \mathrm{~m}$ for the $5 \mathrm{~kg}$ load.

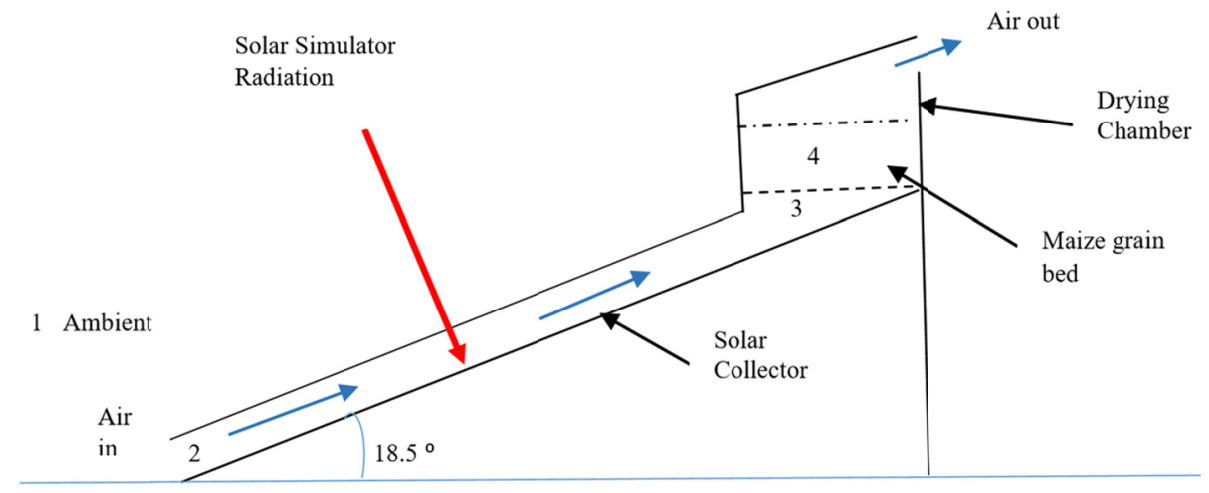

Figure 1. Section through an Indirect-mode Solar Dryer (Simate, 1999). (Position: 1-Ambient, 2-Collector Inlet, 3-Collector Outlet, 4-Grain Bed)

\subsection{Experimentation}

Drying experiments with maize grain were carried out with two loads of $10 \mathrm{~kg}$ and $5 \mathrm{~kg}$ under the same setting of the solar simulator of $634.78 \mathrm{~W} / \mathrm{m}^{2}$ at the University of Newcastle, United Kingdom, by Simate (1999). The temperatures at various locations, i.e. ambient, collector inlet, collector outlet and, grain bed obtained from the drying experiments, were used in the calculations for energy and exergy. The other input to the energy and exergy calculations was the mass air flow rate through the dryer. A validated model that was presented by Simate (2020) was used to calculate the air flow rate.

The Solar Simulator consists of 16 Compact Source Metal Halide Lamps (Iodide) often called CSI type each producing a power of $1 \mathrm{~kW}$. The lights are positioned at a height of about $4 \mathrm{~m}$ above the floor of the room where the drying experiments were done. The CSI solar simulator is recommended for indoor testing of solar collectors (Gillet, 1977). Although it does not provide the exact natural conditions, it produces radiant energy that has a spectral distribution, intensity, uniformity in intensity, and direction close to that of solar radiation and is reliable. 
The spectral range for CSI lamps is $0.3-2 \mu \mathrm{m}$ and falls within that of the sun $(0.3-2.8 \mu \mathrm{m})$. In this study, 11 lamps were used to provide an intensity of $634.78 \mathrm{~W} / \mathrm{m}^{2}$ (standard deviation $57.72 \mathrm{~W} / \mathrm{m}^{2}$ ) on the solar collector. The solar collector area was divided into a grid of 20 positions which gave 20 pyranometer readings. Each pyranometer reading was an average of 20 readings taken at intervals of 15 seconds over a period of 5 minutes. The pyranometer (type W6500 Casella) connected to a Solartron digital multimeter (type 7150 plus) was used to measure the total (beam and diffuse) irradiance falling on the collector. The multimeter gave readings in volts that were then multiplied by the calibration constant of 1.158 to give the intensity in $\mathrm{W} / \mathrm{m}^{2}$. This pyranometer was useful in setting up the solar simulator to give a uniform intensity on the collector area which required fine adjustment of the lamp angles. The accuracy of the Casella W6500 was checked against a Kipp and Zonen pyranometer (model: CM11, irradiance range: $0-1,400 \mathrm{~W} / \mathrm{m}^{2}$, sensitivity: $4-6 \mu \mathrm{V} / \mathrm{Wm}^{-2}$ ). The reading from the Kipp and Zonen pyranometer was slightly higher by $4.69 \%$, and therefore the readings from the Casella were considered accurate.

The other instruments used in the experiments include thermocouples, mercury in glass thermometers, computer, data logger and weighing scale. Mercury in glass thermometers (accuracy $\pm 1 \%$ of full scale reading) placed at position 1 (Figure 1), were used to measure ambient temperature, while temperatures in the solar dryer were measured with copper and copper/constantan type-T thermocouples (measurement range: -200 to $350{ }^{\circ} \mathrm{C}$; sensitivity: $43 \mu \mathrm{V} /{ }^{\circ} \mathrm{C}$; accuracy: $\pm 0.75 \%$ ) at positions 2,3 and 4 as shown in Figure 1. For the temperature at position 4 , thermocouple junctions were inserted into tightly fitting holes drilled into grain kernels and placed at the bottom, middle and top of the grain bed, and the average temperature was then used in the analysis. All the thermocouples were connected to a computer via a data logger (Campbell Scientific CR10X) and adapter (type Isolated Measurement Pods - IMP PC adapter SCHLUMBERGER 35951 A). The thermocouple voltages were converted into digital form by an analogue to digital converter so that they could be read, recorded and displayed on the computer screen.

The moisture content of grain before each experiment was determined using the standard ventilated oven at $130{ }^{\circ} \mathrm{C}$ for 38 hours for maize (BS4317 Part 15, 1981 and ISO 6540, 1980-E). The moisture content of the sample on wet basis was calculated as the ratio of the change in weight of the sample after 38 hours, to the initial weight of the sample. Six grain samples were taken for the initial moisture content determination and the differences between the moisture contents of the samples were less than $0.5 \%$ w.b. The grain samples were weighed with an electronic balance, 1507MP8 Satorius Instruments Ltd. Features of the Sartorius 1507 MP8 Balance, include: Capacity resolution: 5550 x $0.01 \mathrm{~g}$, Linearity: $0.02 \mathrm{~g}$, Range capability: single, Calibration weight: $5000 \mathrm{~g}$, Corner test weight: $5000 \mathrm{~g}$, Corner tolerance: $0.04 \mathrm{~g}$, Preload tolerance: $-150 \pm 20 \mathrm{mV}$ and Calibration weight class: F1.

The drying procedure involved loading the required mass of wet grain $(10 \mathrm{~kg}$ or $5 \mathrm{~kg})$ on the tray. A mechanical balance (Avery 1303 BDL/5049) was used to weigh the grain. The weighing was done by adding some counter weights and bringing the balance reading to zero before putting it into the dryer. Part of the counter weights was an open box containing lead shot. With each lead shot weighing only a few grams, it was possible to get an accurate zero reading on the balance. The wet grain was spread as evenly as possible to make it level, taking care to avoid compacting the grain. Compacting the grain would produce unequal void spaces in the grain bed at different locations that could result in non-uniform air flow and drying. The drying started the moment the tray was loaded into the dryer because the solar simulator lights were switched on one hour before the start of each experiment so as to bring the temperature of the dryer to an almost steady state value. At thirty-minute intervals, the tray was removed from the dryer and put on the balance and the reading brought back to zero by removing some lead shot from the counter weight. The weight of lead shot removed in order to bring the balance to zero after each thirty-minute drying interval gave the weight loss (moisture removed) for that interval. The removed lead shot was weighed on the electronic balance (1507MP8, Satorius Instruments Ltd). With the knowledge of the moisture content of grain at the beginning of the drying experiment, the amount of moisture in the $10 \mathrm{~kg}$ or 5 $\mathrm{kg}$ load of grain was determined. Then for each successive thirty-minute interval, the amount of moisture remaining in the load of grain was determined. The moisture content at the end of each interval was calculated as the ratio of the weight of moisture remaining in the reduced load, to the weight of the reduced load for that interval.

The temperatures at various sections of the solar dryer at different times of the drying process were used to calculate the buoyancy pressure. The air flow through the dryer was consequently determined by balancing the buoyancy pressure with the flow resistance in the solar dryer. This procedure is described by an air flow model presented by Simate (2020) who validated it with measured air flow from a separate experiment done by Simate (1999) under the same setting of the solar simulator of $634.78 \mathrm{~W} / \mathrm{m}^{2}$. The separate experiment to measure air 
flow did not involve removal of the tray containing the maize grain for weighing, as it would have introduced cooler air into the solar dryer and caused the buoyancy pressures and the air flow to reduce. Since the experiments were performed indoors, the effect of external wind velocity on the air flow inside the solar dryer was considered to be very small and therefore negligible.

\subsection{Energy}

The energy entering the solar collector $\left(E N_{\text {sol-in-col }}\right)$ is determined from the incident solar energy received by the collector and is given by equation (1) (Duffie \& Beckman, 2013),

$$
E N_{\text {sol-in-col }}=A_{\text {col }} * I_{\text {sol }}
$$

Where: $A_{\text {col }}$ is the area of the solar collector, $\mathrm{m}^{2}$

$I_{\text {sol }}$ is the incident solar radiation, $\mathrm{W} / \mathrm{m}^{2}$

The energy exiting the solar collector $\left(E N_{\text {out-col }}\right)$ is the useful gain of the solar collector based on the air inlet and outlet temperatures and the air flow; it is given by equation (2) (Duffie \& Beckman, 2013),

$$
E N_{\text {out }-c o l}=M_{a} * C_{p}\left(T_{\text {exit-col }}-T_{\text {in-col }}\right)
$$

Where: $\quad M_{a}$ is the mass air flow rate, $\mathrm{kg} / \mathrm{s}$

$\mathrm{C}_{p}$ is the specific heat capacity of air, $\mathrm{J} / \mathrm{kg}{ }^{\circ} \mathrm{C}$

$T_{\text {exit-col }}$ is the collector exit temperature, ${ }^{\circ} \mathrm{C}$

$T_{\text {in-col }}$ is the collector inlet temperature, ${ }^{\circ} \mathrm{C}$

The specific heat capacity of air $\left(C_{p}=C_{p a}+C_{p v} H\right)$ has two components; the first one is the specific heat of dry air $C_{p a}$, while the second one is the product of specific heat of water vapour $C_{p v}$, and humidity ratio $H$ (Bala \& Woods, 1994). Typical humidity ratios found in this work were around $0.009 \mathrm{~kg}$ water $/ \mathrm{kg}$ dry air. The contribution of the second component to the specific heat capacity of air was therefore considered negligible.

As the solar collector receives energy, some of this energy is lost to the ambient air through the combined convection and radiation resulting in reduced energy output from the collector. Consequently the solar collector energy efficiency $\left(E N_{\text {eff-col }}\right)$ is given by equation (3),

\subsection{Exergy}

$$
E N_{\text {eff-col }}=E N_{\text {out }-\mathrm{col}} / E N_{\text {sol-in-col }}
$$

The exergy entering the collector has two components; the exergy of heat absorbed due to solar radiation and the exergy of the air entering the collector at inlet (Jafarkazemi \& Ahmadifard, 2013). The exergy content of the heat transfer is described by the energy transferred, the temperature of the boundary and the atmospheric reservoir temperature (Bejan, 2016). Therefore, the inlet exergy into the collector due to solar radiation $\left(E X_{\text {sol-in-col }}\right)$ is given by equation (4)

$$
E X_{\text {sol-in-col }}=A_{\text {col }} * I_{\text {sol }}\left(1-\left(T_{a m} / T_{\text {sol }}\right)\right)
$$

Where: $T_{a m}$ is the ambient temperature, $\mathrm{K}$

$T_{\text {sol }}$ is the temperature of the solar simulator. The simulator produces illumination that matches the spectra typically for temperatures in the range $5,000 \mathrm{~K}$ to $6,000 \mathrm{~K}$. (https://g2voptics.com/solar-simulation/\#: :text=The\%20metal\%20halid). An average value of 5,500 $\mathrm{K}$ was used in this analysis.

The exergy of a flowing stream of matter $\left(E X_{\text {flow }}\right)$ can be expressed in terms of physical $\left(E X_{p h}\right)$, chemical $\left(E X_{c h}\right)$, kinetic $\left(E X_{k n}\right)$ and potential $\left(E X_{p o}\right)$ components by equation (5), (Dincer \& Rosen, 2007).

$$
E X_{\text {flow }}=E X_{p h}+E X_{c h}+E X_{k n}+E X_{p o}
$$

For an ideal gas, Benjan (2016) gives a simplified equation for the specific flow exergy $\left(e_{x}\right)$ as given by equation (6)

$$
e_{x}=c_{p} T_{o}\left(\frac{T}{T_{o}}-1-\ln \frac{T}{T_{o}}\right)+R T \ln \frac{P}{P_{o}}
$$

Assuming that the change in pressure between the inlet and outlet of the solar dryer is negligible and incorporating the mass air flow, equation (6) is simplified to equations (7) and equation (8) and used to calculate the exergy of air at inlet and outlet of the solar collector, respectively. The exergy of air entering the collector $\left(E X_{\text {air-in-col }}\right)$ is based on the collector inlet temperature $\left(T_{i n-c o l}\right)$ and is given by equation (7): 


$$
E X_{a i r-i n-c o l}=M_{a} C_{p}\left[T_{i n-c o l}-T_{a m}-T_{a m} \ln \left(T_{i n-c o l} / T_{a m}\right)\right]
$$

The exergy of air coming out of the collector $\left(E X_{\text {air-out-col }}\right)$ is based on the collector outlet temperature $\left(T_{\text {out-col }}\right)$ and is given by equation (8):

$$
E X_{\text {air-out }-c o l}=M_{a} C_{p}\left[T_{\text {out }-c o l}-T_{a m}-T_{\text {am }} \ln \left(T_{\text {out }-c o l} / T_{\text {am }}\right)\right]
$$

The exergy efficiency of the solar collector $\left(E X_{\text {eff-col }}\right)$ is the ratio of the increase in air flow exergy to the exergy input into the collector from solar radiation $\left(E X_{\text {sol-in-col }}\right)$. It is given by equation (9) (Zhong et al., 2014).

$$
E X_{\text {eff-col }}=\left(E X_{\text {air-out-col }}-E X_{\text {air-in-col }}\right) / E X_{\text {sol-in-col }}
$$

The exergy of air entering the drying chamber $\left(E X_{i n-d c h}\right)$ is the same as that coming out of collector and is given by equation (8). The exergy of air entering the drying chamber is equal to the sum of the different exergies in the drying chamber and is given by equation (10) (Dincer \& Rosen, 2007),

$$
E X_{\text {in-dch }}=E X_{\text {product }}+E X_{\text {waste }}+E X_{\text {destruction }}
$$

The exergy emitted with waste to the outside of the dryer $\left(E X_{\text {waste }}\right)$ and the exergy destruction due to internal irreversibility $\left(E X_{\text {destruction }}\right)$, together constitute the exergy loss in the drying chamber $\left(E X_{\text {loss }}\right)$.

For a natural convection solar dryer, the exergy output in the product $\left(E X_{\text {product }}\right)$ is the rate of heat consumed in evaporating moisture from the grain and is determined by equation (11) (Kumar et al., 2017),

$$
E X_{\text {product }}=Q_{\text {evap }}\left(1-T_{a m} / T_{\text {grain-bed }}\right)
$$

Where: $Q_{\text {evap }}$ is the heat used for evaporation of moisture from the grain, $\mathrm{J} / \mathrm{s}$; and is given by equation (12).

$m_{\text {evap }}$ is the rate of moisture evaporation, $\mathrm{kg} / \mathrm{s}$.

$h_{f g}$ is the latent heat of vaporisation, $\mathrm{J} / \mathrm{kg}$; evaluated at the temperature in the grain bed, $T_{\text {grain-bed }}$.

$$
Q_{\text {evap }}=m_{\text {evap }} h_{f g}
$$

The exergy efficiency of the drying chamber is the ratio of the exergy input for evaporation of moisture in the grain to the exergy of drying air supplied (Dincer \& Rosen, 2007; Hepbasli, 2008), and is given by equation (13),

\section{Results and Discussion}

$$
E X_{\text {eff-dch }}=E X_{\text {product }} / E X_{\text {in-dch }}
$$

Figure 2 shows the temperatures at various locations of the solar dryer for the $10 \mathrm{~kg}$ and $5 \mathrm{~kg}$ loads from the drying experiments. The average temperature rise in the collector (difference between air temperature at collector exit and inlet) for the $10 \mathrm{~kg}$ load is $36.89^{\circ} \mathrm{C}$ whereas that for the $5 \mathrm{~kg}$ load is $31.78^{\circ} \mathrm{C}$. The temperature rise for the $10 \mathrm{~kg}$ load is higher due to lower air flow in this load. For both loads, the air temperature in the grain bed increases from a value equal to the ambient temperature to the maximum at the end of drying. 


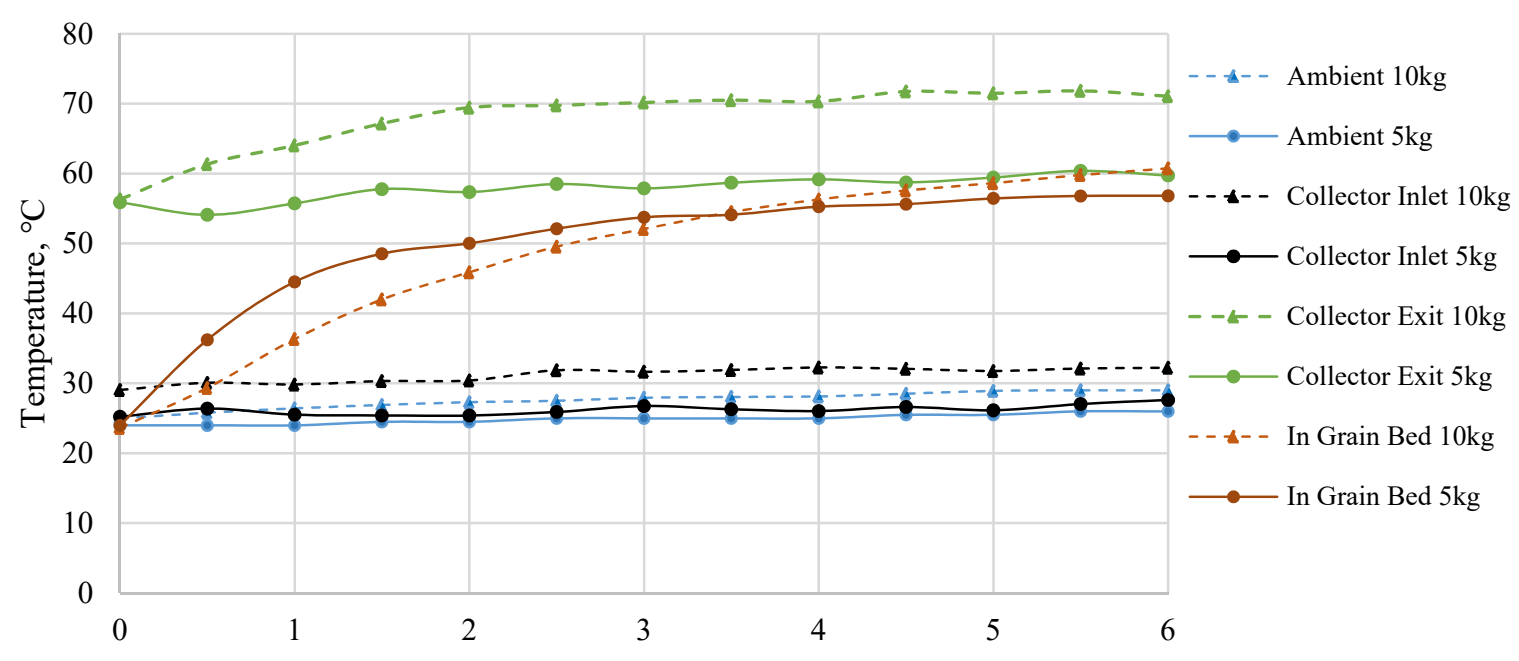

Drying Time, hours

Figure 2. Temperatures at various positions in the solar dryer for the $10 \mathrm{~kg}$ and $5 \mathrm{~kg}$ loads from Simate (1999)

Figure 3 shows the variation of air flow with drying time in the solar dryer for $10 \mathrm{~kg}$ and $5 \mathrm{~kg}$ loads as determined by the air flow model (Simate, 2020) using temperature values from Figure 2. The air flow values were used in the calculations of energy and exergy. The mass air flow for the $10 \mathrm{~kg}$ load varies from $0.0045 \mathrm{~kg} / \mathrm{s}$ at the start of drying to $0.0077 \mathrm{~kg} / \mathrm{s}$ at the end of drying, whereas for the $5 \mathrm{~kg}$ it is from $0.0074 \mathrm{~kg} / \mathrm{s}$ to 0.0117 $\mathrm{kg} / \mathrm{s}$. The average air flow in the $5 \mathrm{~kg}$ load is higher than that in the $10 \mathrm{~kg}$ load by $64.1 \%$. The higher air flow in the $5 \mathrm{~kg}$ load is due to the reduced resistance to air flow by the $5 \mathrm{~kg}$ grain bed as its thickness is half that of the $10 \mathrm{~kg}$ bed.

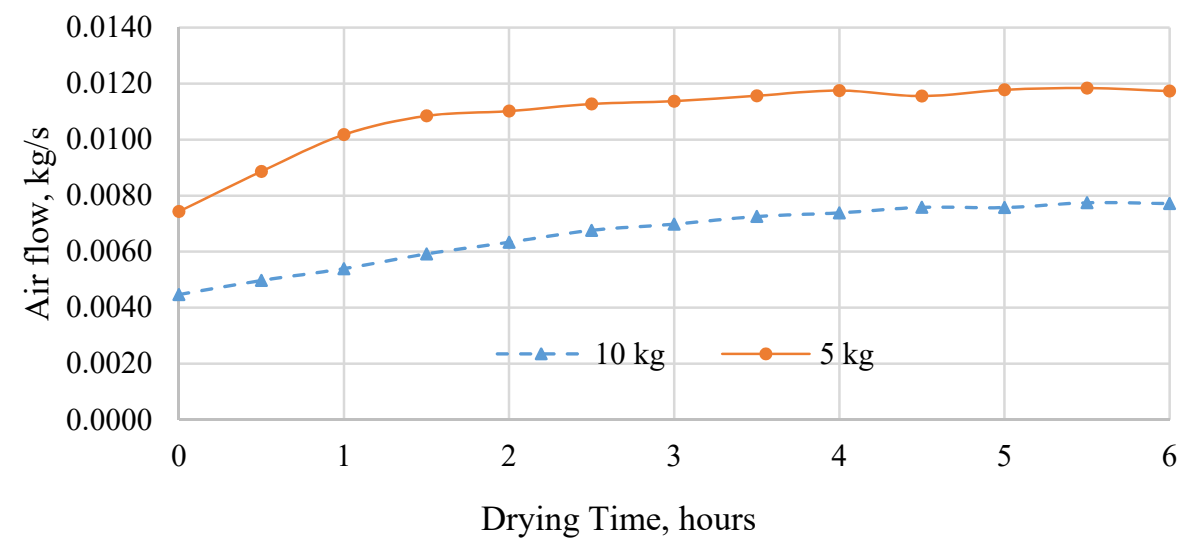

Figure 3. Air flow in the solar dryer for $10 \mathrm{~kg}$ and $5 \mathrm{~kg}$ loads calculated using air flow model presented by Simate (2020)

Figure 4 shows the variation of moisture content with drying time from drying experiments done by Simate (1999). The initial moisture contents are $25.3 \%$ and $24.7 \%$ for the $10 \mathrm{~kg}$ and $5 \mathrm{~kg}$ loads, respectively. The moisture contents reached after six hours of drying are $13.99 \%$ and $12.56 \%$ for the $10 \mathrm{~kg}$ and $5 \mathrm{~kg}$ loads, respectively, and are slightly higher than the $12.5 \%$ value that is recommended for safe storage of maize. It is worth noting that the drying could have continued beyond the six hours period and the grain could have attained moisture content of less than $12.5 \%$. Nonetheless, these reductions in moisture contents obtained during the six-hour period, represent significant amounts of moisture evaporated from the grain and are considered adequate for this analysis. The drying curves are quite similar with the moisture contents not very different from 
each other and reducing by $11.3 \%$ and $12.1 \%$ for the $10 \mathrm{~kg}$ and $5 \mathrm{~kg}$ loads, respectively. The moisture evaporated is used in the calculation of the exergy of evaporation in the drying chamber.

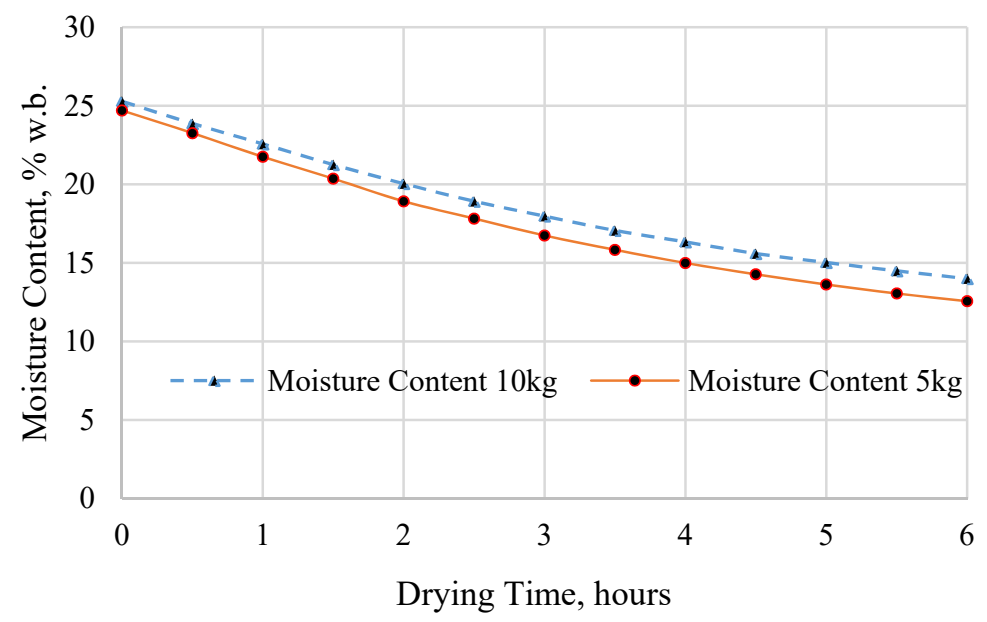

Figure 4. Moisture content of grain from Simate (1999)

Figures 5 shows the energy and exergy efficiencies of the solar collector in the $10 \mathrm{~kg}$ and $5 \mathrm{~kg}$ loads against drying time. The energy extracted in the $5 \mathrm{~kg}$ load is higher than that in the $10 \mathrm{~kg}$ load despite the solar collector receiving the same amount of energy from the solar simulator during the two experiments. This can be attributed to the higher air flow in the $5 \mathrm{~kg}$ load since air flow is related to heat transfer from the collector absorber surface to the air. The energy efficiency range is from 32.0 to $49.7 \%$ for the $5 \mathrm{~kg}$ load and 19.5 to $39.5 \%$ for the $10 \mathrm{~kg}$ load. The low energy efficiency values seen in the early stages of drying could be attributed to more energy being used in sensible heating of the collector to bring it to its operating temperature. The values found in this work are comparable to what other researchers found. Boulemtafes-Boukadoum and Benzaoui (2011) obtained values ranging from 10 to $30 \%$ with flow under the absorber in natural convection solar drying of mint. Bennamoun (2012) used a forced convection solar collector with flow under the absorber and found the efficiency was variable and could reach as high as $60 \%$. The efficiency was found to be strongly dependent on the absorbed radiations and collector outlet temperatures. Oztop, Bayrak and Hepbasli (2013) reviewed a number of studies on solar air heaters with various heat transfer enhancement techniques and found that their energy efficiencies were in the range of 47 to $89 \%$.

Figure 5 also shows the exergy efficiency plotted against drying time. The average exergy efficiencies are $2.4 \%$ and $2.6 \%$ for the $10 \mathrm{~kg}$ and $5 \mathrm{~kg}$ loads respectively, and are lower than the energy efficiencies. Tiwari, Des, Chen and Barnwel (2009) in the greenhouse drying of fish, and Subramani, Dana, Natesan, and Leo (2020) in the greenhouse drying of ivy gourd and turkey berry, also found that the exergy efficiency was lower than the energy efficiency and attributed this to some of the input exergy being destroyed due to irreversibility.

It is further noted in Figure 5 that the exergy efficiencies in the two loads are almost equal even though the collector energy efficiency in the $5 \mathrm{~kg}$ load is higher than that in the $10 \mathrm{~kg}$ load. The $5 \mathrm{~kg}$ load extracts more energy from the collector due to higher air flow, but this does not translate into a corresponding higher magnitude of exergy efficiency compared to the $10 \mathrm{~kg}$ load as the two exergies are similar, differing by $0.2 \%$. This implies that the work potentials of the collectors in both loads are the same. This is reasonable since the study is dealing with the same solar dryer operating under similar conditions of solar intensity except carrying a different load for each experiment. Jafarkazemi and Ahmadifard (2013) observed that energy and exergy efficiencies have conflicting behaviours, noting that an increase in mass flow rate causes an increase in energy efficiency of the collector while it causes a decrease in the exergy efficiency. Optimizing the dryer based on exergy would show how sensitive exergy is to the mass air flow and collector exit temperature. Both air flow and collector exit temperature are important factors in the drying of grain; the air exiting the collector being at a higher temperature than the grain, evaporates moisture from the grain while the same air, due to its motion, takes the evaporated moisture to the outside of the dryer. According to Benjan (2016), a system's ability to produce work is affected by the temperature of the boundary crossed by the heat if it differs from the atmospheric temperature. For a natural convection solar dryer, the grain depth affects the air flow and temperature of air at 
collector exit differently. Thus a reduction in grain bed thickness increases air flow rate in the dryer due to a lower pressure drop across the grain bed, while the temperature at collector exit decreases.

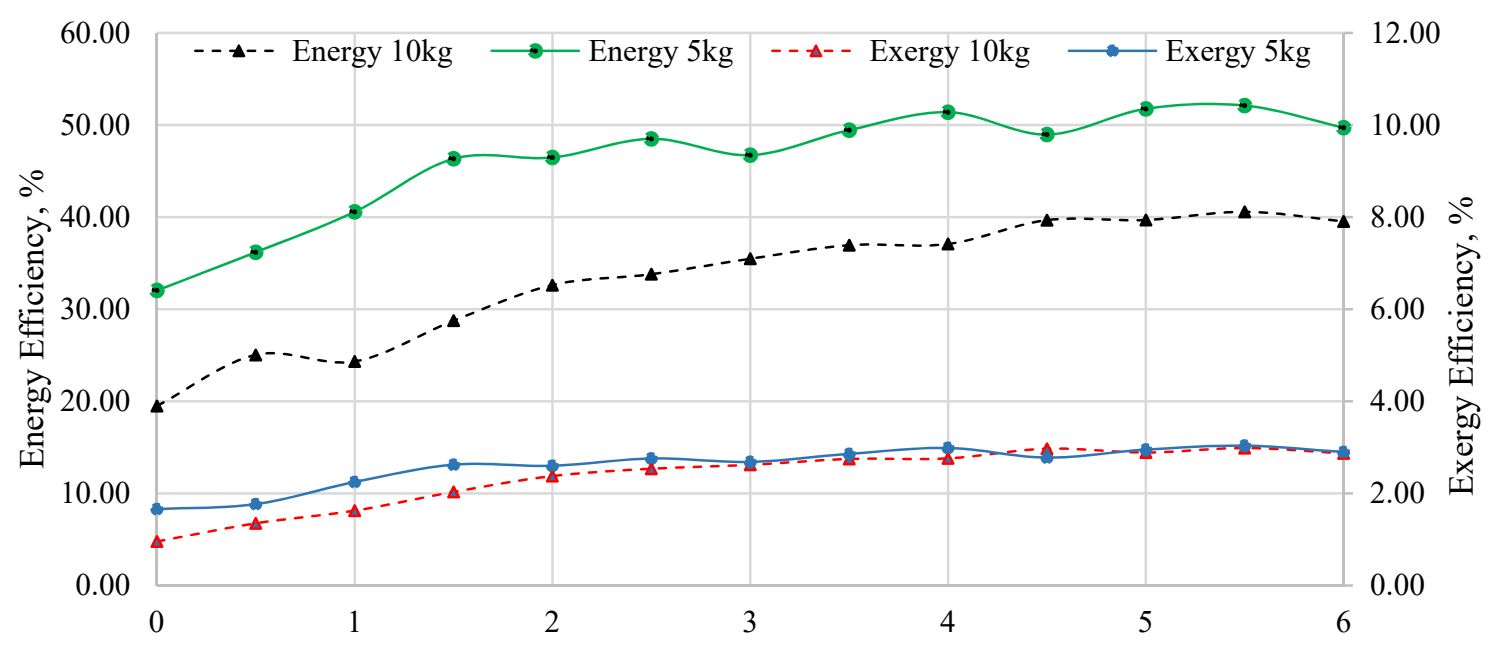

Drying Time, hours

Figure 5. Energy and Exergy Efficiencies of the Solar Collector

Figure 6 shows the different exergies in the drying chamber, i.e. air inlet, product (evaporation) and loss inside, plotted against drying time for the $10 \mathrm{~kg}$ and $5 \mathrm{~kg}$ loads. For both loads, the air inlet exergy is low in the early stages of drying because the air being supplied to the drying chamber from the collector has a lower temperature. A big quantity of the energy received by the collector is used to raise the collector temperature hence air with lower temperature being supplied to the drying chamber in the early stages of drying.

The product exergy reaches a maximum at about 1.5 to 2 hours from the start of drying due to increased rate of evaporation, before reducing gradually towards the end of drying due to reduced evaporation as the grain dries and less energy is utilised in evaporation. In general, the $5 \mathrm{~kg}$ load has a lower product exergy due to less moisture evaporated compared to the $10 \mathrm{~kg}$ load.

The $5 \mathrm{~kg}$ load exhibits a higher exergy loss compared to the $10 \mathrm{~kg}$ load. This can be attributed to more emissions to the surroundings as hot air from the collector is not fully utilised in removing moisture from the grain. The smaller grain surface area for the $5 \mathrm{~kg}$ load, compared to the $10 \mathrm{~kg}$ load, translates into less amount of heat transferred from the hot air to the grain resulting in less moisture evaporated from the grain. The unutilised heat is then lost to the surroundings. 


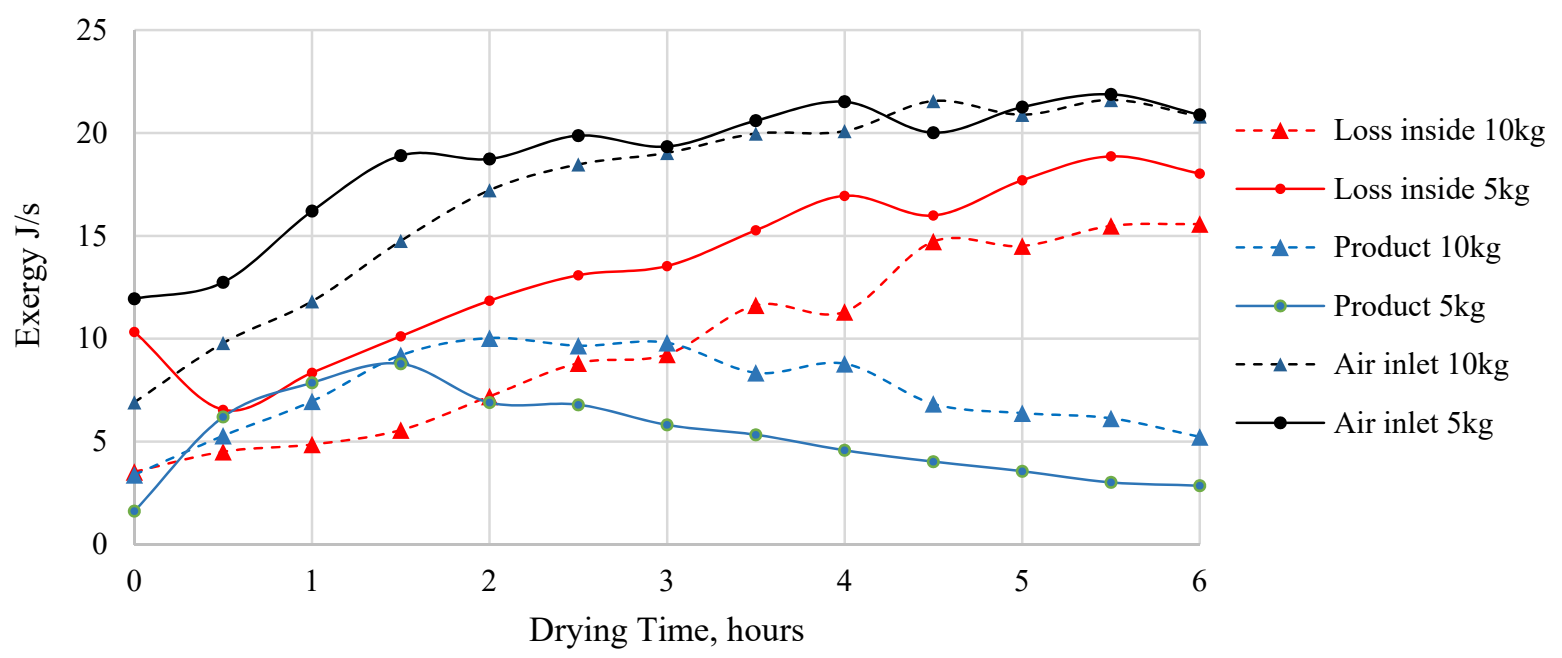

Figure 6. Exergy of the Drying Chamber

Figure 7 shows the exergy efficiency in the drying chamber based on the moisture evaporated from the grain. The $10 \mathrm{~kg}$ load has a higher exergy efficiency as a result of higher evaporation of moisture from the grain bed. It can be seen that there is an increase in exergy efficiency during the first 1.5 hours of drying followed by gradual reduction up to the end of drying. The increase in exergy in the early stages of drying may not be rapid because the drying was done under constant radiation intensity of the solar simulator. However, Arepally, Ravula, Malik, and Kamidi (2017) found a sharp increase in exergy efficiency during the first half of the day and a sharp decline during the second half of the day in the drying of tomato slices in a mixed mode natural convection solar dryer. The variation of the exergy efficiency followed the changes in the solar radiation intensity.

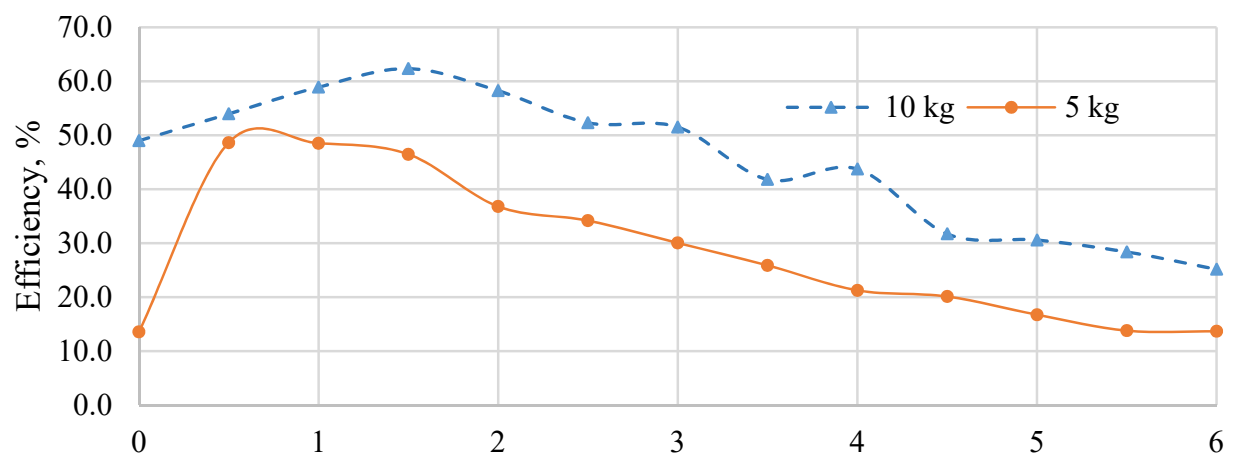

Drying Time, hours

Figure 7. Exergy Efficiency of the Drying Chamber

Table 1 shows the average energy and exergy efficiencies in the solar collector and drying chamber and the magnitude of the different exergies in the drying chamber for the $10 \mathrm{~kg}$ and $5 \mathrm{~kg}$ loads. The collector energy efficiency in $5 \mathrm{~kg}$ load is higher than that in the $10 \mathrm{~kg}$ load by $12.9 \%$, while in terms of exergy efficiency, it is only higher by $0.2 \%$. It can be seen that the $5 \mathrm{~kg}$ load is more efficient at extracting energy from the collector but less efficient in utilising the extracted energy to evaporate moisture from the grain which has resulted in a lower drying chamber exergy efficiency. It can also be seen that the exergy loss in the drying chamber for the 5 $\mathrm{kg}$ load is higher than that for the $10 \mathrm{~kg}$ load. The $5 \mathrm{~kg}$ load has a lower exergy of product (evaporation) than the 
$10 \mathrm{~kg}$. In both loads, the exergy loss is higher than the exergy of product which implies that less exergy was used for moisture evaporation as most of the exergy was lost due to irreversibility and as waste.

Table 1. Average Energy and Exergy Parameters in the Collector and Drying Chamber

\begin{tabular}{lcc}
\hline \multicolumn{1}{c}{ Parameter } & 10 kg load & $5 \mathrm{~kg}$ load \\
\hline Solar Collector Energy Efficiency, \% & 33.3 & 46.2 \\
Solar Collector Exergy Efficiency, \% & 2.4 & 2.6 \\
Exergy of Air entering the Drying Chamber, J/s & 17.2 & 18.8 \\
Exergy of Product, J/s & 7.4 & 5.2 \\
Exergy Loss in the Drying Chamber, J/s & 9.8 & 13.6 \\
Drying Chamber Exergy Efficiency, \% & 45.2 & 28.4 \\
\hline
\end{tabular}

\section{Conclusion}

In this work energy and exergy analysis is performed on the indirect mode solar dryer operating under natural convection with air flow over the absorber and using two different loads of maize grain of $5 \mathrm{~kg}$ and $10 \mathrm{~kg}$. The temperatures at various locations, i.e. ambient, collector inlet, collector outlet/drying chamber inlet and, grain bed obtained from the drying experiments, and air flow calculated using a model, are used in the calculations for energy and exergy.

The energy efficiency in the collector for the $5 \mathrm{~kg}$ load is higher than that in the $10 \mathrm{~kg}$ load, and this can be attributed to the higher air flow in the $5 \mathrm{~kg}$ load since air flow is related to heat transfer from the collector absorber surface to the air.

Although the collector for the $5 \mathrm{~kg}$ load has a higher energy efficiency than the $10 \mathrm{~kg}$ load, this does not translate into a corresponding higher magnitude of exergy efficiency compared to the $10 \mathrm{~kg}$ load. The exergy or potential to do work by the collector in the two loads is the same, and this is reasonable since the same solar dryer is used under the same solar intensity for each load.

For the drying chamber, the exergy loss due to irreversibility is lower for the $10 \mathrm{~kg}$ as it utilises more exergy in evaporating moisture from the grain due to the larger grain surface area for heat transfer compared to the $5 \mathrm{~kg}$ load. Consequently, the drying chamber exergy efficiency is higher for the $10 \mathrm{~kg}$ load.

Based on the results and the analyses done, it can be concluded that a relatively thin grain bed produces a higher air flow through the dryer resulting in better solar collector energy efficiency. However, a thin grain bed gives a higher exergy loss in the drying chamber due to lower utilisation of heat to evaporate moisture from the grain resulting in lower drying chamber exergy efficiency. A bigger grain bed is therefore better at utilising the exergy to evaporate moisture from the grain. However, to obtain the optimum size of grain bed, optimisation techniques are recommended.

\section{Acknowledgments}

The author wishes to acknowledge the financial support from the University of Zambia which made it possible for the research to be carried out. Further acknowledgement goes to the University of Newcastle through Dr. J. L. Woods for the guidance throughout the project.

\section{References}

Adelaja, A. O., \& Babatope, B. I. (2013). Analysis and Testing of a Natural Convection Solar Dryer for the Tropics. Hindawi Publishing Corporation Journal of Energy, 2013, Article ID479894, 8. https://doi.org/10.1155/2013/479894

Akpinar, E. K. (2018). The effects of some Exergetic Indicators on the Performance of Thin Layer Drying Process of Long Green Pepper in a Solar Dryer. Heat and Mass Transfer, 55, 299-308. https://doi.org/10.1007/s00231-018-2415-2

Arepally, D., Ravula, S. R., Malik, G. K., \& Kamidi, V. R. (2017). Mathematical Modelling, Energy and Exergy Analysis of Tomato Slices in a Mixed Mode Natural Convection Solar Dryer. Chemical Science International Journal, 20(4), 1-11, 2017; Article no. CSIJ.34878 ISSN: 2456-706X. https://doi.org/10.9734/CSJI/2017/34878

Bala, B. K., \& Woods, J. L. (1994). Simulation of the Indirect Natural Convection Solar Drying of Rough Rice. Solar Energy, 53(3), 259-266. https://doi.org/10.1016/0038-092X(94)90632-7 
Bejan, A. (2016). Advanced Engineering Thermodynamics, Fourth Edition, John Wiley \& Sons, Inc., Hoboken, New Jersey. https://doi.org/10.1002/9781119245964

Bennamoun, L. (2012). An Overview on Application of Exergy and Energy for Determination of Solar Drying Efficiency. International Journal of Energy Engineering, 2(5), 184-194. https://doi.org/10.5923/j.jijee.20120205.01

Berinyuy, J. E., Tangka, J. K., \& Weka Fotso, G. M. (2012). Enhancing Natural Convection Solar Drying of High Moisture Vegetables with Heat Storage, Agric Eng Int: CIGR Journal, 14(1), 141-148. https://cigrjournal.org/index.php/Ejounral/article/download/1610/1550

Bolaji, B. O. (2011). Exergetic Analysis of Solar Energy drying Systems. Natural Resources, 2, 92-97. https://doi.org/10.4236/nr.2011.22012

Boulemtafes-Boukadoum, A., \& Benzaoui, A. (2011). Energy and Exergy analysis of Solar Drying process of Mint. Energy Procedia, 6, 583-591. Science Direct. https://doi.org/10.1016/j.egypro.2011.05.067

Daud, L. E. I., \& Simate, I. N. (2017). Drying Kinetics of Sliced Pineapples in a Solar Conduction Dryer. Energy and Environment Research, 7(2). https://doi.org/10.5539/eer.v7n2p14

Dincer, I., \& Rosen, M. A. (2007). Exergy - Energy, Environment and Sustainable Development, 103-126. Elsevier Science, $\quad 9780080531359$. https://www.scribd.com/book/282478235/Exergy-Energy-Environment-and-Sustainable-Development

Duffie, J. A., \& Beckman, W. A. (2013). Solar Engineering of Thermal Processes, John Wiley \& Sons, Inc., Hoboken, New Jersey, Fourth Edition, 236-321. https://doi.org/10.1002/9781118671603

Elavarasan, R., Dhanushkodi, S., \& Sudhakar, K. (2018). Energy and Exergy Analysis of a Natural Convection Solar Dryer, International Journal of Mechanical Engineering and Technology, 9(6), 769-775. $\mathrm{http} / / / \mathrm{www}$. iaeme.com/ijmet/issues.asp?JType=IJMET\&VType=9\&IType $=6$

Gillet, W. B. (1977). Solar Simulators and Indoor Testing. UK International Solar Energy Society Conference, London, 30-48.

Hatami, S., Payganeh, G., \& Mehrpanahi, A. (2020). Energy and Exergy analysis of an Indirect Solar Dryer based on a Dynamic Model. Journal of Cleaner Production, 244, 20 January 2020, 118809. https://doi.org/10.1016/j.jclepro.2019.118809

Hepbasli A. (2008). A Key Review on Exergetic analysis and assessment of Renewable Energy Resources for a Sustainable Future. Renewable and Sustainable Energy Reviews, 12, 593-661, Science Direct. https://doi.org/10.1016/j.rser.2006.10.001

Jafarkazemi, F., \& Ahmadifard, E. (2013). Energetic and Exergetic evaluation of Flat Plate Solar Collectors, Renewable Energy, 56, 55-63. https://doi.org/10.1016/j.renene.2012.10.031

Kumar A., Ranjan S., Prakash O., \& Shukla, A. (2017). Exergy Analysis of Solar Dryers. In: Prakash O., Kumar A. (eds) Solar Drying Technology - Concept, Design, Testing, Modeling, Economics, and Environment. $\begin{array}{lllll}\text { Green Energy and Technology. Springer, } & \text { Singapore. }\end{array}$ https://doi.org/10.1007/978-981-10-3833-4_8

Oztop, H. F., Bayrak, F., \& Hepbasli, A. (2013). Energetic and Exgertic aspects of Solar Air Heating (solar collector) Systems. Renewable and Sustainable Energy Reviews, 21, 59-83. https://doi.org/10.1016/j.rser.2012.12.019

Panwar, N. L., Kaushik. S. C., \& Kothari, S. (2016). Thermal Modeling and Experimental validation of Solar Tunnel Dryer: A clean Energy option for Drying Surgical Cotton. International Journal of Low-Carbon Technologies, 11, 16-28. https://doi.org/10.1093/ijlct/ctt053

Simate, I. N. (2020). Air Flow Model for Mixed-Mode and Indirect-Mode Natural Convection Solar Drying of Maize. Energy and Environment Research, 10(2). https://doi.org/10.5539/eer.v10n2p1

Simate, I. N. (1999). Mixed Mode Solar Drying (Unpublished Ph.D. Thesis). University of Newcastle upon Tyne, United Kingdom.

Simate, I. N., \& Ahrné, L. M. (2006). Dehydration of Tropical Fruits. In: Handbook of Food Technology and Food Engineering. Editor: Y. H. Hui. Publisher: Marcel Dekker. https://doi.org/10.1201/b15995-116 
Simate, I. N., \& Cherotich, S. (2017). Design and Testing of a Natural Convection Solar Tunnel Dryer for Mango. Hindawi Journal of Solar Energy, 2017, Article ID 4525141, 10. https://doi.org/10.1155/2017/4525141

Subramani, S., Dana, S. S., Natesan, V. T., \& Leo, G. M. L. (2020). Energy And Exergy Analysis Of Greenhouse Drying Of Ivy Gourd And Turkey Berry. Thermal Science, 24(1B), 645-656. https://doi.org/10.2298/TSCI190602459S

Tiwari, G. N., Des, T., Chen, C. R., \& Barnwel, P. (2009). Energy and exergy analyses of greenhouse fish drying. International Journal of Exergy, 6(5), 620 -636. https://doi.org/10.1504/IJEX.2009.027493

Zhong, G., Huitao, W., Hua, W., Songyuan, Z., \& Xin, G. (2014). Exergy Analysis of Flat Plate Solar Collectors. Entropy, 16, 2549-2567. https://doi.org/10.3390/e16052549

\section{Copyrights}

Copyright for this article is retained by the author(s), with first publication rights granted to the journal.

This is an open-access article distributed under the terms and conditions of the Creative Commons Attribution license (http://creativecommons.org/licenses/by/3.0/). 